\title{
An open diachronic corpus of historical Spanish
}

\author{
Felipe Sánchez-Martínez, Isabel Martínez-Sempere, \\ Xavier Ivars-Ribes, Rafael C. Carrasco \\ Dep. Llenguatges i Sistemes Informàtics, \\ Universitat d'Alacant, E-03071, Alacant, Spain \\ fsanchez@dlsi.ua.es
}

\begin{abstract}
The IMPACT-es diachronic corpus of historical Spanish compiles over one hundred books - containing approximately 8 million words - in addition to a complementary lexicon which links more than 10 thousand lemmas with attestations of the different variants found in the documents. This textual corpus and the accompanying lexicon have been released under an open license (Creative Commons BY-NC-SA) in order to permit their intensive exploitation in linguistic research.

Approximately $7 \%$ of the words in the corpus (a selection aimed at enhancing the coverage of the most frequent word forms) have been annotated with their lemma, part of speech, and modern equivalent. This paper describes the annotation criteria followed and the standards, based on the Text Encoding Initiative recommendations, used to represent the texts in digital form.
\end{abstract}

Keywords: diachronic corpus; historical Spanish; linguistic annotation; TEI

\section{Introduction}

Diachronic corpora are a valuable source of information with which to understand the historical evolution of languages. Unfortunately, diachronic collections are relatively scarce - at least, when compared to the overwhelming availability of resources containing transcriptions of modern text or speech (Kocjančič, 2009; Procházková, 2006; Davies, 2010a; Francis and Kucera, 1979)—, since creating a diachronic corpus is a costly task. The transcription of old texts must be manually reviewed because a number of features - such as spelling variations, old fonts, deprecated characters, and blurred text caused by stains or page transparency - may cause the accuracy of the automatic process of converting printed text into computer-encoded text (commonly referred to as OCR or Optical Character Recognition) to fall below acceptable rates. In the particular case of Spanish, access to suitable linguistic resources can be challenging since the most renowned on-line diachronic resources, such as the Corpus Diacrónico del Español —CORDE (Real Academia Española, s.a.)—, and the Corpus del Español (Davies, 2002) can be consulted only via Web interfaces ${ }^{1}$ which provide limited querying capabilities (Davies, 2010b).

\footnotetext{
${ }^{1}$ See http://corpus.rae.es/cordenet.html and http://www.corpusdelespanol.org, respectively.
}

Author Posting. (c) 2013 Springer Science+Business Media Dordrecht The final publication is available at link.springer.com http://link.springer.com/article/10.1007/s10579-013-9239-y 
This paper describes the IMPACT-es diachronic corpus of historical Spanish and the accompanying lexicon created by IMPACT, ${ }^{2}$ a research project funded by the European Commission under its seventh Framework Programme and focused on the improvement of the precision of OCR and the access to historical texts. The components developed in IMPACT include:

- Historical language resources for nine European languages which have allowed significant improvements to be made —up to a 30\% (de Does and Depuydt, 2012) - in OCR word recall rates for historical documents in addition to increased productivity when used in combination with postcorrection tools.

- A toolkit (Depuydt and de Does, 2009) with which to build lexical resources, tools for their deployment - both in OCR and information retrieval applications - , and named entity recognition tools for historical documents.

- Better OCR engines with improved technologies for image enhancement, binarisation, character recognition and algorithms for layout detection.

- A large ground-truth data set (a collection of images mapped onto extremely accurate transcriptions), coupled with a comprehensive evaluation toolkit.

- A framework of service and workflow layers (Neudecker et al, 2011) which enables full flexibility between all the IMPACT components.

In particular, the IMPACT-es corpus contains 107 Spanish texts first printed between 1481 and 1748 and covering a representative variety of authors and genres (prose, theatre, and verse). The digital versions in the corpus are based on early editions or faithful reprints of the early editions. This content is divided into two separate sections:

1. The GT section which compiles the 21 Spanish documents in the groundtruth data set created by IMPACT.

2. The BVC section which compiles 86 texts provided by the Biblioteca Virtual Miguel de Cervantes ${ }^{3}$ digital library and which have been partially annotated as will be described later.

Moreover, the corpus is complemented with a lexicon that links more than 10 thousand lemmas - corresponding to the most frequent word forms-, with a representative sample of attestations in the corpus. The full IMPACT-es corpus and the accompanying lexicon are available under the Creative Commons Attribution-NonCommercial-ShareAlike 3.0 license $^{4}$ and can be downloaded at the IMPACT Centre of Competence Website. ${ }^{5}$ A compact version of the lexicon, with no quotes from the corpus, has also been released under a dual license Creative Commons Attribution-ShareAlike $3.0^{6}$ and GNU GPL v $3^{7}$ - in order to encourage its integration into free/open-source tools for the analysis and partof-speech tagging of historical Spanish texts (Sánchez-Marco et al, 2011) such as FreeLing (Carreras et al, 2004).

\footnotetext{
${ }^{2}$ IMproving ACcess to Text, http://www.impact-project.eu

${ }^{3}$ http://www.cervantesvirtual.com

${ }^{4}$ http://creativecommons.org/licenses/by-nc-sa/3.0/

${ }^{5} \mathrm{http}: / /$ www.digitisation.eu/tools/language-resources/impact-es/

${ }^{6}$ http://creativecommons.org/licenses/by-sa/3.0/

${ }^{7}$ http://www.gnu.org/licenses/gpl.html
} 
To the best of our knowledge, this is the first diachronic corpus of historical Spanish distributed under an open license. In addition to the aforementioned CORDE and Corpus del Español, some other collections serve specific purposes. For example, the Corpus de Documentos Españoles Anteriores a $1700-$ CODEA (Sánchez-Prieto Borja, 2012) — contains over 1,500 documents, written between the 12th and 17th centuries, mainly collected from archives (for example, letters and administrative, legal and ecclesiastic documents). The project Website ${ }^{8}$ provides an interface through which to access the palaeographic and critical editions on a single-document basis. The Corpus Histórico del Español en México - CHEM, (Medina Urrea and Méndez Cruz, 2011) - collects documents written between the 16th and the 20th centuries, but the access to the collection is restricted to text visualisation. ${ }^{9}$

The rest of the paper is organised as follows. The following section provides an overview of the source documents in the IMPACT-es corpus. Section 3 then describes the annotation process and the criteria followed in the annotation. The markup format used to encode the documents that integrate the corpus and the lexicon is presented in Section 4. Finally, some concluding remarks are presented in Section 5.

\section{Corpus description}

The IMPACT-es corpus was created to assist in the improvement of OCR techniques by allowing the integration of specific vocabularies in the digitisation process in both information retrieval services and comprehensive evaluation frameworks. The selection of content and the annotation criteria have therefore been oriented towards this objective: for instance, the original spelling (even if clearly unintentional) has been preserved by the accurate transcription performed to create the ground-truth documents.

The GT section of the IMPACT-es corpus compiles 21 texts printed between 1543 and 1748, and contains around 6 million (unannotated) words with a transcription accuracy (as compared to the original text) of over $99.95 \%$. The author, title and dates of the first and source edition of the constituent documents are listed in Appendix A.

In order to ensure the $99.95 \%$ fidelity to the source texts in the GT section we followed the standard acceptance sampling (Montgomery, 2009, part 6) statistical procedure for quality control: each document was processed in batches (containing between 500 and 1200 pages) in which each page was scanned and the automatic transcription obtained from the scanned image was manually corrected; when the transcription of a whole batch was complete, a sample containing about $4 \%$ of the pages was randomly selected and reviewed by an external quality control team; whenever the accuracy of the digitisation was found to be below $99.95 \%$, the whole batch was rejected and its processing restarted.

The BVC section of the corpus compiles 86 texts printed between 1482 and 1990 which are listed in Appendix B together with the dates of the first and source editions. These documents contain approximately 2 million words and a significant fraction of this content — over $27 \%$ of the section-, has been manually annotated with linguistic metadata. ${ }^{10}$

\footnotetext{
${ }^{8}$ http://demos.bitext.com/codea

${ }^{9} \mathrm{http}: / /$ www.iling.unam.mx/chem/

${ }^{10}$ Although the number of works in the BVC section is about four times the number of works
} 
Table 1: Part of speech tags and their relative frequencies in the annotated part of the corpus.

\begin{tabular}{clr}
\hline Tag & Part of speech & Frequency \\
\hline abr & abbreviation & $0.03 \%$ \\
adj & adjective & $10.70 \%$ \\
adv & adverb & $2.92 \%$ \\
cnj & conjunction & $1.08 \%$ \\
det & determiner & $2.64 \%$ \\
ij & interjection & $0.19 \%$ \\
n & noun & $29.41 \%$ \\
np & proper noun & $7.63 \%$ \\
num & numeral & $0.39 \%$ \\
pr & preposition & $1.59 \%$ \\
prn & pronoun & $7.25 \%$ \\
rel & relative pronoun & $0.17 \%$ \\
verb & verb & $36.00 \%$ \\
\hline
\end{tabular}

The corpus is accompanied by a lexicon which links more than 10 thousand entries (simple or compound lemmas) with their attestations in the BVC section of the corpus. The historical variants are classified under lemma, part of speech and modern form (see Figure 4 on page 10 for an example). Each occurrence of a variant is associated with the context in which it appears (10 preceding and 10 trailing words) and a reference to the document that contains it (title, author, dates of the first and source editions). The lexicon has been generated in parallel with the linguistic markup, and an ample coverage of lemmas and word forms was sought. Higher priority for their inclusion in the lexicon has therefore been given to the forms with a greater frequency. Since some words are very frequent, at most 500 occurrences per lemma have been annotated and therefore registered in the lexicon.

The metadata added to Spanish words are lemma (in modern form), part of speech and modern equivalent. The words originating from other languages (less than $0.1 \%$, and principally Latin) are labelled solely with their language. The part-of-speech categories and their tags - shown in Table 1 together with their relative frequencies - are based on those defined by the Apertium machine translation platform (Forcada et al, 2011) for the dictionaries in the Spanish-Catalan language pair since, to the best of our knowledge, there is no Spanish diachronic lexicon available in digital form under a free/open-source license. Having a lexicon in digital form facilitated the manual annotation of the corpus as described below.

\section{Annotation process and criteria}

The annotation was assisted by the CoBaLT tool (Kenter et al, 2012), a Webbased editor which supports the annotation of corpora and creation of corpusbased lexicons. In addition the tool allows a common annotation to be assigned to a sequence of consecutive words, and also accepts compound lemmas and

in the GT section, it contains only one third of the word forms because the six volumes of the Diccionario de la lengua castellana account for 4 million word forms in the GT section. 
compound part-of-speech categories.

For the annotation of the corpus we used the 22nd edition of the Diccionario de la Lengua Española (Real Academia Española, 2001a) as a primary reference in determining the lemmas. For archaisms, the on-line version of the Nuevo Tesoro Lexicográfico de la Lengua Española (Real Academia Española, 2001b), which compiles Spanish historical dictionaries dating from 1726 (up to the 21st edition of the Diccionario de la Lengua Española), was employed as a secondary reference.

The annotation process was as follows. Initially, the texts (in plain text format), and a lexicon with pre-annotated word forms obtained from the Apertium dictionary aforementioned, were loaded into the CoBaLT tool. The texts were then tokenised and the word forms sorted by their frequency. Finally, the most frequent word forms were annotated. During the annotation, CoBaLT presented every word form and its attestations, and used the lexicon to suggest the lemma, modern equivalent and part-of-speech category. This lexicon was incrementally updated to simplify the annotation of word forms with multiple occurrences.

The following criteria have been applied during the annotation of the BVC section:

- Modern forms with compound lemmas: word forms which cannot be associated with a single lemma - such as verbs with enclitic pronouns and contractions - are marked with a compound lemma and a compound partof-speech tag. For example arrepiéntase has the compound lemma arrepentir + se and the compound part-of-speech tag verb+prn.

- Word boundaries: whenever two or more consecutive words in the transcription correspond to a single modern form (for example aun que becomes aunque), the word group receives a shared annotation with single lemma and single part of speech. Conversely, when one old form corresponds to a sequence of modern forms (for example quel becomes que el), they are tagged with a compound lemma and a compound part of speech.

- Archaisms: when the reference dictionary (Real Academia Española, 2001a) registers a word as an archaism with a modern equivalent, the modern form has been preferred for the lemma. For example apercibir is the lemma assigned to the word form apercebir.

- Numbers: all cardinal numbers share a single part-of-speech category (called num). The original style - alphabetic characters, Arabic or Roman figureshas been preserved in the associated metadata. If they are split, as is the case of the historical variant diez y seis, then they are handled as if they were different words in the sentence.

- Optional diacritics: optional diacritics used only for disambiguation (for example, in the words sólo, éste, ése, and aquél) have been preserved in the associated metadata (lemma and modern form).

- Apocopation: the full form has been preferred as the lemma for words with apocopation. For example algún is a form with the lemma alguno.

- Past participles: past participles have been classified as verbs only if they follow an auxiliary verb (some cases of haber or ser), or they are not described as adjectives in the reference dictionary (e.g., dormido). 
- Proper nouns: all lemmas and modern forms, with the exception of proper nouns, are written in lower case letters. The modern form of proper nouns, when available, has been preferred in the annotation to the word form in the source text; for example, the modern form and lemma of Quixote is Quijote.

We have not split those word forms that are annotated with a compound lemma and a compound part of speech because they are written as single forms both in old and modern Spanish. A shared annotation has been assigned to those contiguous old word forms which in modern Spanish are written as a single word form. However, those contiguous old word forms that express numbers have been annotated independently of one another because they may either refer to a single number (e.g. dieciséis, Spanish word for sixteen) or to different numbers (e.g. diez y seis, Spanish words for six and ten).

\section{Markup schema}

The IMPACT-es corpus is distributed as a collection of XML files, each of which corresponds to a different work, and organised in one folder per section. The XML standard (World Wide Web Consortium, 2008) specifies how metadata must be inserted in a digital text in the form of tags which serve to identify the nested elements that make up the logical structure of the document. The names of the elements and their attributes (optional features whose value can make the meaning of the tag more specific) are defined by the annotation schema. In this case, the markup vocabulary follows the Text Encoding Initiative P5 Guidelines. ${ }^{11}$

The TEI vocabulary is widely and actively used in digitisation projects in the area of humanities, example of which are: Europeana Regia, ${ }^{12}$ the Perseus Digital Library, ${ }^{13}$ or the British National Corpus. ${ }^{14}$ The TEI vocabulary defines a rich variety of elements such as paragraphs, words, and characters, in addition to a number of optional attributes - such as type or language - for each element, and only a reduced subset has therefore been employed in this case. Other corpora released in the scope of the IMPACT project use a similar TEI vocabulary (Erjavec, 2012).

Every document in the corpus is encoded in a single XML file whose root element (with tag TEI) contains a header (under the element tag teiHeader) with descriptive metadata of the document (marked as fileDesc) - , and a body (body) - with the digitised content structured in one or more divisions (elements div) - . The descriptive metadata element includes the bibliographical description of the source (under tag $b i b l$ ) together with the information concerning the digital edition (under tag editionStmt). The bibliographic descriptions, illustrated in Figure 1, consist of a title element, an author element, the year of the first edition (as a date element with a first-edition value of the type attribute), and the year of the source edition (as a date second element with a source-edition value of the type attribute).

Figure 2 illustrates the elements and attributes employed in the annotation of the BVC section within a single main division (element with a div tag) for each document:

\footnotetext{
${ }^{11}$ http://www.tei-c.org/release/doc/tei-p5-doc/en/html

${ }^{12}$ http://www.europeanaregia.eu

${ }^{13}$ http://www.perseus.tufts.edu

${ }^{14}$ http://www.natcorp.ox.ac.uk
} 


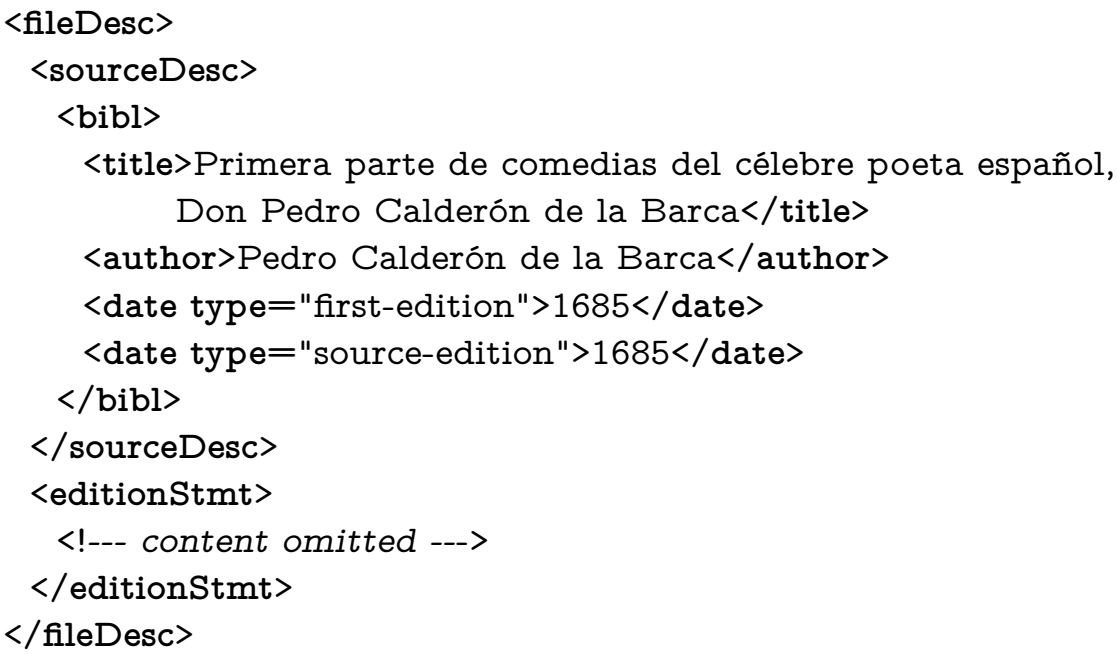

Figure 1: Fragment showing the bibliographical metadata encoded in the header of one of the documents.

- Anonymous blocks (an element with an $a b$ tag) contain one block of text (e.g., a paragraph or header) in the document.

- Every anonymous block contains one or more words (elements with a w tag). Foreign words have a single attribute defined, xml:lang, which stores the language of the word. In contrast, Spanish words are annotated with the following metadata:

- The lemma is stored as the value of the lemma attribute.

- The part-of-speech category is the value of the type attribute.

- The original and modern equivalent are provided as the content of orig element tags (defined by TEI as an element with which to mark a piece of text as following the original) and reg (defined as an element with which to mark a reading which has in some respect been regularised) under the choice element tag.

- Punctuation characters ( $p c$ tag) and other characters ( $c$ tag) can appear between the words.

The subset of tags described above is similar to that used by Sánchez Marco et al (2009).

The GT section documents contain one division per page (see Figure 3) which accepts some sub-elements:

- Page number, drop capital, footnote and table-of-content entries are tagged as anonymous blocks with the specific values (page-number, drop-capital, footnote, and TOC-entry) of their type attribute.

- A heading is tagged as a head element.

- Paragraphs are marked with a $p$ tag.

Other constituents of the source document, such as figures, catchwords - words placed at the foot of a page to anticipate the first word of the following page or glosses were not digitised owing to the OCR orientation of the corpus. 


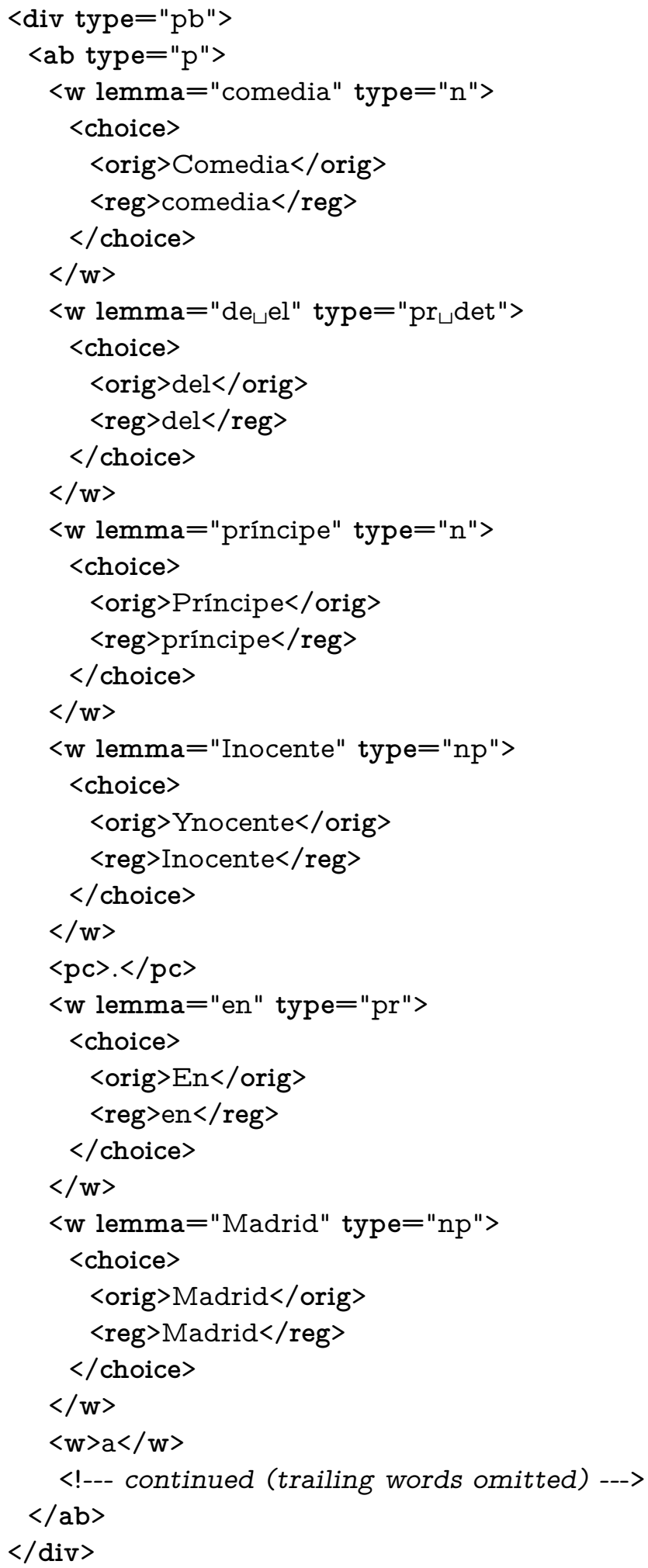

Figure 2: Excerpt showing the content of one block element in the body of a TEI encoded document in the BVC section of the corpus. 


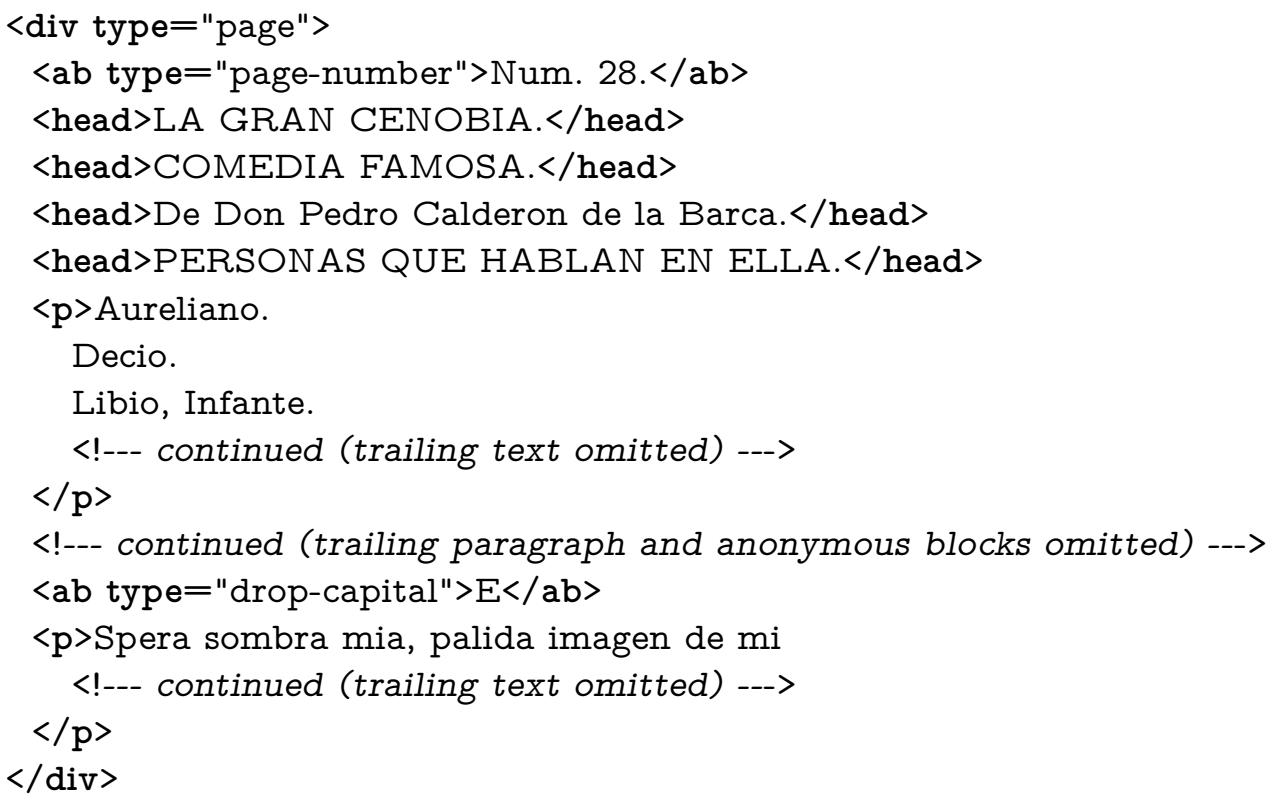

Figure 3: Excerpt showing one page element of a document in the GT section.

Because of its specific nature, a different subset of elements defined by the TEI P5 guidelines (module "9 dictionaries") has been employed for the lexicon (see Figure 4). Indeed, the body of the lexicon document consists of entries (elements with an entry tag) which contain:

- A lemma as an element with a form name (a form is defined by TEI as an element which groups all the information concerning the written and spoken forms of one headword) and the lemma value of its type attribute.

- A number of modern variants of the lemma, labelled as elements with a form name and a modern-form value of their type attribute.

On the one hand, every form element of a lemma type contains:

- The lemma under the orth TEI element (which is defined as the orthographic form of a dictionary headword).

- The part-of-speech category (under the gram element that provides grammatical information in a gramGrp element).

- The number of annotated occurrences in the collection, given by the content of a $l b l$ element with an occurrences type.

On the other hand, every form element of a modern-form type contains:

- The orthographic variant, as the content of an orth element.

- One or more form elements with historical-form type which contains the historical forms (orthographic variant) as the content of an orth sub-element and a number of attestations as the content of a cit sub-element.

Finally, every attestation contains the following information: 


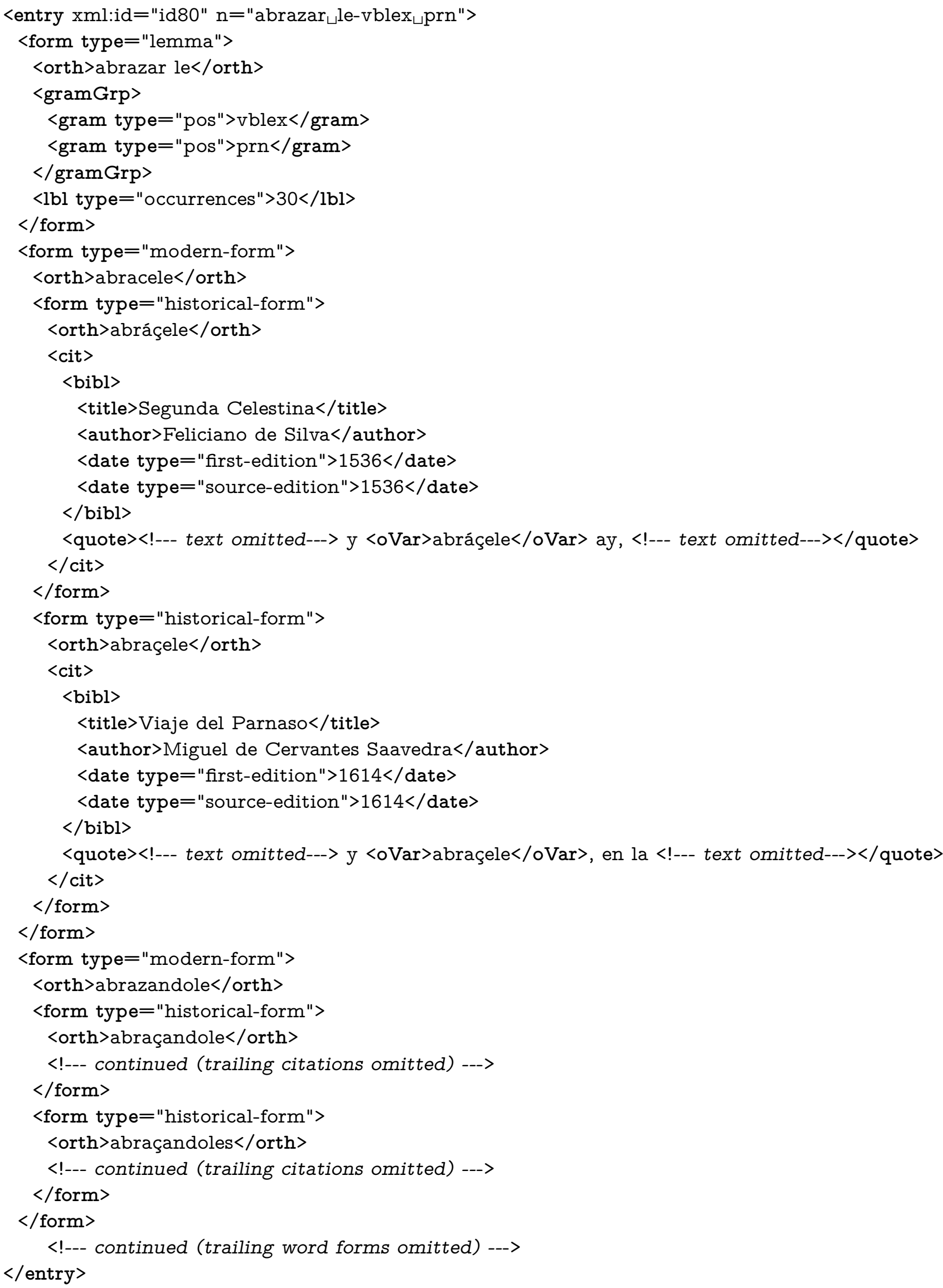

Figure 4: Example of an entry in the lexicon. 
- The bibliographical information (within the $b i b l$ element), i.e. the reference of the work cited.

- A number of quotes within the quote element in which the historical form is labelled with the $o$ Var tag.

\section{Concluding remarks}

The IMPACT-es open diachronic corpus of historical Spanish contains approximately 8 million words and has been released under an open license (Creative Commons BY-NC-SA). We have described the criteria applied for the linguistic annotation - of nearly $7 \%$ of the words in the corpus - with lemmas, parts of speech and modern equivalents.

The corpus is divided into two sections: the BVC section (from the Biblioteca Virtual Miguel de Cervantes digital library), which has been manually annotated, and the GT section (developed by the IMPACT project), which has been digitised with a fidelity of $99.95 \%$ to the original. Furthermore, a lexicon has been extracted from the BVC section. Every entry in the lexicon corresponds to one lemma and part of speech, and contains a sample of variants and their attestations in the corpus.

\section{Acknowledgements}

Work funded by the European Commission under the Seventh Framework Programme (FP7) through the IMPACT (IMproving ACcess to Text) project. We thank Mikel L. Forcada for his fruitful suggestions. 


\section{A Content: the GT section}

\begin{tabular}{|c|c|c|}
\hline Author: Title & $\begin{array}{l}\text { First } \\
\text { edition }\end{array}$ & $\begin{array}{l}\text { Source } \\
\text { edition }\end{array}$ \\
\hline \multicolumn{3}{|l|}{ Anonymous: } \\
\hline Vida de Lazarillo de Tormes & 1554 & 1652 \\
\hline \multicolumn{3}{|l|}{ Francisco de Quevedo: } \\
\hline El Parnasso español & 1648 & 1648 \\
\hline \multicolumn{3}{|l|}{ Garcilaso de la Vega: } \\
\hline $\begin{array}{l}\text { Obras de Garcilasso de la Vega con las anota- } \\
\text { ciones por el Mtro. Francisco Sánchez Brocense }\end{array}$ & 1574 & 1612 \\
\hline \multicolumn{3}{|l|}{ Inca Garcilaso de la Vega: } \\
\hline Commentarios reales & 1609 & 1609 \\
\hline \multicolumn{3}{|l|}{ Jorge Juan: } \\
\hline $\begin{array}{l}\text { Observaciones astronomicas y phisicas hechas de } \\
\text { orden de S. M. en los Reynos del Peru }\end{array}$ & 1748 & 1748 \\
\hline \multicolumn{3}{|l|}{ Juan Boscán: } \\
\hline $\begin{array}{l}\text { Las obras de Boscán y algunas de Garcilasso de } \\
\text { la Vega repartidas en cuatro libros }\end{array}$ & 1543 & 1543 \\
\hline \multicolumn{3}{|l|}{ Lope de Vega: } \\
\hline Las comedias del famoso poeta Lope de Vega & 1604 & 1604 \\
\hline \multicolumn{3}{|l|}{ Luis de Góngora: } \\
\hline $\begin{array}{l}\text { El Polifemo de Don Luis de Góngora with com- } \\
\text { ments by Don García de Salzedo }\end{array}$ & 1629 & 1629 \\
\hline \multicolumn{3}{|l|}{ Mateo Alemán: } \\
\hline $\begin{array}{l}\text { Vida y hechos del pícaro Guzmán de Alfarache } \\
\text { Miguel de Cervantes Saavedra: }\end{array}$ & Miguel de Cervantes Saavedra: & 1681 \\
\hline El ingenioso hidalgo Don Quixote de la Mancha & 1605 & 1605 \\
\hline \multicolumn{3}{|l|}{ Pedro Calderón de la Barca: } \\
\hline $\begin{array}{l}\text { Primera parte de comedias del célebre poeta es- } \\
\text { pañol, Don Pedro Calderón de la Barca }\end{array}$ & 1685 & 1685 \\
\hline \multicolumn{3}{|l|}{ Real Academia Española de la Lengua: } \\
\hline $\begin{array}{l}\text { Diccionario de la lengua castellana }[\ldots] \text { Tomo } \\
\text { primero. Que contiene las letras A, B }\end{array}$ & 1726 & 1726 \\
\hline $\begin{array}{l}\text { Diccionario de la lengua castellana }[\ldots] \text { Tomo } \\
\text { segundo. Que contiene la letra C }\end{array}$ & 1729 & 1729 \\
\hline $\begin{array}{l}\text { Diccionario de la lengua castellana }[\ldots] \text { Tomo } \\
\text { tercero. Que contiene las letras D, E, F }\end{array}$ & 1732 & 1732 \\
\hline $\begin{array}{l}\text { Diccionario de la lengua castellana }[\ldots] \text { Tomo } \\
\text { quarto. Que contiene las letras G, H, I, J, K, L, } \\
\text { M, N }\end{array}$ & 1734 & 1734 \\
\hline $\begin{array}{l}\text { Diccionario de la lengua castellana }[\ldots] \text { Tomo } \\
\text { quinto. Que contiene las letras } \mathrm{O}, \mathrm{P}, \mathrm{Q}, \mathrm{R}\end{array}$ & 1737 & 1737 \\
\hline $\begin{array}{l}\text { Diccionario de la lengua castellana }[\ldots] \text { Tomo } \\
\text { sexto. Que contiene las letras S, T, V, X, Y, Z }\end{array}$ & 1739 & 1739 \\
\hline \multicolumn{3}{|l|}{ Ruy López de Sigura: } \\
\hline $\begin{array}{l}\text { Libro de la invención liberal y arte del juego del } \\
\text { Axedrez }\end{array}$ & 1561 & 1561 \\
\hline
\end{tabular}




\begin{tabular}{lcc}
\hline Author: Title & $\begin{array}{c}\text { First } \\
\text { edition }\end{array}$ & $\begin{array}{c}\text { Source } \\
\text { edition }\end{array}$ \\
\hline $\begin{array}{l}\text { San Juan de la Cruz: } \\
\quad \text { Obras del venerable y mistico Dotor F. Joan de }\end{array}$ & 1629 & 1629 \\
$\quad$ la Cruz & & \\
$\begin{array}{l}\text { Santa Teresa de Jesús: } \\
\quad \text { Los libros de la Madre Teresa de Jesús }\end{array}$ & 1588 & 1588 \\
$\quad \begin{array}{l}\text { Sor Juana Inés de la Cruz: } \\
\quad \text { Carta athenagorica }\end{array}$ & 1690 & 1690 \\
\hline
\end{tabular}




\section{B Content: the BVC section}

\begin{tabular}{|c|c|c|}
\hline Author: Title & $\begin{array}{l}\text { First } \\
\text { edition }\end{array}$ & $\begin{array}{l}\text { Source } \\
\text { edition }\end{array}$ \\
\hline \multicolumn{3}{|l|}{ Baltasar Gracián: } \\
\hline Oráculo manual y arte de la prudencia & 1647 & 1647 \\
\hline \multicolumn{3}{|l|}{ Beato Juan de Ávila: } \\
\hline Epistolario espiritual & 1578 & 1962 \\
\hline \multicolumn{3}{|l|}{ Cristóbal de Castillejo: } \\
\hline Dialogo de mujeres & 1544 & 1544 \\
\hline Obras morales y de devoción & 1542 & 1958 \\
\hline \multicolumn{3}{|l|}{ Diego Sánchez de Badajoz: } \\
\hline Farsa de Abraham & 1554 & 1554 \\
\hline Farsa de la muerte & 1554 & 1554 \\
\hline Farsa racional del libre alvedrío & 1554 & 1554 \\
\hline \multicolumn{3}{|l|}{ Feliciano de Silva: } \\
\hline Segunda Celestina & 1536 & 1536 \\
\hline \multicolumn{3}{|l|}{ Fernando Rojas: } \\
\hline La Celestina & 1499-1502 & 1499,1514 \\
\hline \multicolumn{3}{|l|}{ Fernán Pérez de Oliva: } \\
\hline Dialogo de la dignidad del hombre & 1585 & 1586 \\
\hline \multicolumn{3}{|l|}{ Francisco de la Torre: } \\
\hline Poesías & Various & 1969 \\
\hline \multicolumn{3}{|l|}{ Francisco Delicado: } \\
\hline La Lozana Andaluza & 1528 & 1528 \\
\hline \multicolumn{3}{|l|}{ Gabriel Lobo Lasso de la Vega: } \\
\hline Tragedia de la honra de Dido restaurada & 1587 & 1587 \\
\hline \multicolumn{3}{|l|}{ Guillén de Castro: } \\
\hline Las Mocedades del Cid & $1605-1615$ & 1618 \\
\hline \multicolumn{3}{|l|}{ Ínigo de Mendoza: } \\
\hline Coplas de Vita Christi Frayy & 1482 & 1482 \\
\hline \multicolumn{3}{|l|}{ Juan Boscán: } \\
\hline Obra completa & Various & 1917 \\
\hline \multicolumn{3}{|l|}{ Juan Cortés de Tolosa: } \\
\hline El desgraciado & 1617 & 1620 \\
\hline El nacimiento de la verdad & 1617 & 1620 \\
\hline La Comadre & 1617 & 1620 \\
\hline Novela del licenciado periquín & 1617 & 1620 \\
\hline Novela de un miserable llamado Gonzalo & 1617 & 1620 \\
\hline \multicolumn{3}{|l|}{ Juan de Encina: } \\
\hline $\begin{array}{l}\text { Égloga representada en la noche postrera de Car- } \\
\text { nal }\end{array}$ & 1496 & 1496 \\
\hline Aucto del repelón & 1509 & 1509 \\
\hline Égloga de Cristino y Febea & 1509 & 1509 \\
\hline Égloga de Fileno, Zambardo y Cardonio & 1509 & 1509 \\
\hline Égloga de las grandes lluvias & 1507 & 1507 \\
\hline Égloga de Mingo, Gil y Pascuala & 1496 & 1496 \\
\hline Égloga de Plácida y Vitoriano & 1513 & 1962 \\
\hline
\end{tabular}




\begin{tabular}{|c|c|c|}
\hline Author: Title & $\begin{array}{l}\text { First } \\
\text { edition }\end{array}$ & $\begin{array}{l}\text { Source } \\
\text { edition }\end{array}$ \\
\hline Representación sobre el poder del amor & 1507 & 1507 \\
\hline \multicolumn{3}{|l|}{ Juan de Mena: } \\
\hline Laberinto de Fortuna & 1481 & 1505 \\
\hline \multicolumn{3}{|l|}{ Juan Ruiz de Alarcón y Mendoza: } \\
\hline El antichristo & 1634 & 1990 \\
\hline El desdichado en fingir & 1628 & 1990 \\
\hline El dueño de las estrellas & 1634 & 1990 \\
\hline El tejedor de Sevilla & 1634 & 1990 \\
\hline Examen de maridos & 1634 & 1990 \\
\hline Ganar amigos & 1634 & 1990 \\
\hline La amistad castigada & 1634 & 1990 \\
\hline La crueldad por el honor & 1634 & 1990 \\
\hline La cueva de Salamanca & 1628 & 1990 \\
\hline La industria y la suerte & 1628 & 1990 \\
\hline La manganilla de Melilla & 1634 & 1990 \\
\hline La prueba de las promesas & 1634 & 1990 \\
\hline Los empeños de un engaño & 1634 & 1990 \\
\hline Los pechos privilegiados & 1634 & 1990 \\
\hline Mudarse por mejorarse & 1628 & 1990 \\
\hline Todo es ventura & 1628 & 1990 \\
\hline \multicolumn{3}{|l|}{ Lope de Vega: } \\
\hline Comedia del Príncipe Ynocente & 1590 & 1762 \\
\hline \multicolumn{3}{|l|}{ Luis Vélez de Guevara: } \\
\hline La serrana de la Vera & 1613 & 1916 \\
\hline \multicolumn{3}{|l|}{ Miguel de Cervantes Saavedra: } \\
\hline Comedia del çerco de Numancia & 1615 & 1615 \\
\hline $\begin{array}{l}\text { Comedia famosa de la casa de los zelos y seluas } \\
\text { de Ardenia }\end{array}$ & 1615 & 1615 \\
\hline Comedia famosa del gallardo español & 1615 & 1615 \\
\hline Comedia famosa del laberinto de amor & 1615 & 1615 \\
\hline Comedia famosa de los baños de Argel & 1615 & 1615 \\
\hline Comedia famosa de Pedro de Vrdemalas & 1615 & 1615 \\
\hline Comedia famosa intitvlada el rvfian Dichoso & 1615 & 1615 \\
\hline $\begin{array}{l}\text { Comedia famosa intitvlada la gran svltana doña } \\
\text { Catalina de Ouiedo }\end{array}$ & 1615 & 1615 \\
\hline Comedia llamada Trato de Argel & 1615 & 1615 \\
\hline Don Quijote de la Mancha ( $1^{\mathrm{a}}$ parte $)$ & 1605 & 1605 \\
\hline Don Quijote de la Mancha ( $2^{\mathrm{a}}$ parte $)$ & 1615 & 1615 \\
\hline Entremes de la cueua de Salamanca & 1615 & 1615 \\
\hline $\begin{array}{l}\text { Entremes de la eleccion de los alcaldes de Da- } \\
\text { ganço }\end{array}$ & 1615 & 1615 \\
\hline Entremes de la guarda cuydadosa & 1615 & 1615 \\
\hline Entremes del juez de los diuorcios & 1615 & 1615 \\
\hline Entremes del retablo de las marauillas & 1615 & 1615 \\
\hline Entremes del rufian viudo, llamado Trampagos & 1615 & 1615 \\
\hline Entremes del viejo zeloso & 1615 & 1615 \\
\hline Entremes del vizcayno fingido & 1615 & 1615 \\
\hline
\end{tabular}




\begin{tabular}{lcc}
\hline Author: Title & $\begin{array}{c}\text { First } \\
\text { edition }\end{array}$ & $\begin{array}{c}\text { Source } \\
\text { edition }\end{array}$ \\
\hline La entretenida & 1615 & 1615 \\
La Española inglessa & 1613 & $1613 / 1614$ \\
La Galatea & 1585 & 1585 \\
Novela de la Fuerça de la sangre & 1613 & $1613 / 1614$ \\
Novela de la Gitanilla & 1613 & $1613 / 1614$ \\
Novela de la Illustre Fregona & 1613 & $1613 / 1614$ \\
Novela del amante liberal & 1613 & $1613 / 1614$ \\
Novela de las dos Donzellas & 1613 & $1613 / 1614$ \\
Novela de la Señora Cornelia & 1613 & $1613 / 1614$ \\
Novela del Casamiento engañoso & 1613 & $1613 / 1614$ \\
Novela del Licenciado Vidriera & 1613 & $1613 / 1614$ \\
Novela del Zeloso estremeño & 1613 & 1788 \\
Novela de Rinconete y Cortadillo & 1613 & 1788 \\
Novelas exemplares & 1613 & $1613 / 1614$ \\
Novela y coloquio que passó entre Cipion y & 1613 & $1613 / 1614$ \\
Bergança, perros del hospital de la Resureccion & & \\
Ocho comedias y ocho entremeses nuevos & 1615 & 1615 \\
Persiles y Sigismunda & 1617 & 1617 \\
Poesías sueltas & 1615 & 1615 \\
Viaje del Parnaso & 1614 & 1614 \\
\hline
\end{tabular}

\section{References}

Carreras X, Chao I, Padró L, Padró M (2004) FreeLing: an open-source suite of language analyzers. In: Proceedings of the 4th International Conference on Language Resources and Evaluation, Lisbon, Portugal, pp 239-242

Davies M (2002) Un corpus anotado de 100.000 .000 palabras del español histórico y moderno. Procesamiento del Lenguaje Natural 29:21-27

Davies M (2010a) The corpus of contemporary American English as the first reliable monitor corpus of English. Literary and Linguistic Computing 25(4):447464

Davies M (2010b) Creating useful historical corpora: A comparison of CORDE, the Corpus del Español, and the Corpus do Português. In: Diacronía de las lenguas iberorromances: nuevas perspectivas desde la lingüística de corpus, Vervuert/Iberoamericana, Frankfurt, Germany/Madrid, Spain, pp 137-166

Depuydt K, de Does J (2009) Fons Verborum. Feestbundel voor prof. dr. A.M.F.J. (Fons) Moerdijk, aangeboden door vrienden en collega's bij zijn afscheid van het INL, Instituut voor Nederlandse Lexicologie, Leiden/Amsterdam, chap Computational Tools and Lexica to Improve Access to Text., pp 187-199

de Does J, Depuydt K (2012) Lexicon-supported OCR of eighteenth century Dutch books: a case study. In: Proceedings of the 20th Document Recognition and Retrieval Conference, San Francisco, CA USA, (to appear)

Erjavec T (2012) The goo300k corpus of historical Slovene. In: Proceedings of the Eight International Conference on Language Resources and Evaluation, European Language Resources Association (ELRA), Istanbul, Turkey 
Forcada ML, Ginestí-Rosell M, Nordfalk J, O’Regan J, Ortiz-Rojas S, Pérez-Ortiz JA, Sánchez-Martínez F, Ramírez-Sánchez G, Tyers FM (2011) Apertium: a free/open-source platform for rule-based machine translation. Machine Translation 25(2):127-144

Francis WN, Kucera H (1979) Brown corpus manual. Online at http://www.hit. uib.no/icame/brown/bcm.html

Kenter T, Erjavec T, Dulmin MZ, Fiser D (2012) Lexicon construction and corpus annotation of historical language with the CoBaLT editor. In: Proceedings of the 6th Workshop on Language Technology for Cultural Heritage, Social Sciences, and Humanities, Association for Computational Linguistics, Avignon, France, pp 1-6

Kocjančič P (2009) Internet y los recursos lingüísticos para la lengua española: diccionarios y corpus. Verba hispanica: anuario del Departamento de la Lengua y Literatura Españolas de la Facultad de Filosofía y Letras de la Universidad de Ljubljana 17:145-164

Medina Urrea A, Méndez Cruz CF (2011) El corpus histórico del español en México. Revista Digital Universitaria 12(7):3-25

Montgomery DC (2009) Introduction To Statistical Quality Control. John Wiley \& Sons

Neudecker C, Schlarb S, Dogan M, Missier P, Sufi S, Williams A, Wolstencroft K (2011) An experimental workflow development platform for historical document digitisation and analysis. In: Proceedings of the 2011 Workshop on Historical Document Imaging and Processing, Beijing, China, pp 161-168

Procházková P (2006) Fundamentos de la lingüística de corpus. Concepción de los corpus y métodos de investigación con corpus. Available online at http://prochazkova.de/fundamentos_de_la_lingüística_de_corpus.pdf

Real Academia Española (2001a) Diccionario De La Lengua Española, 22nd edn. Espasa Calpe, Madrid, online at http://lema.rae.es/drae

Real Academia Española (2001b) Nuevo tesoro lexicográfico de la lengua española, 1st edn. Espasa Calpe, Madrid, online at http://buscon.rae.es/ntlle/ SrvltGUILoginNtlle

Real Academia Española (s.a.) Banco de datos CORDE, corpus diacrónico del español. Online at http://corpus.rae.es/cordenet.html, last accessed 2012.09.24

Sánchez Marco C, Boleda G, Fontana JM (2009) Propuesta de codificación de la información paleográfica y lingüística para textos diacrónicos del español. uso del estándar TEI. In: Proceedings of the Congreso Internacional Tradición e innovación: Nuevas perspectivas para la edición y el estudio de documentos antiguos, Madrid, Spain

Sánchez-Marco C, Boleda G, Padró L (2011) Extending the tool, or how to annotate historical language varieties. In: Proceedings of the 5th ACL-HLT Workshop on Language Technology for Cultural Heritage, Social Sciences, and Humanities, Portland, OR, USA, pp 1-9 
Sánchez-Prieto Borja P (2012) Desarrollo y explotación de un corpus de documentos españoles anteriores a 1700 (CODEA). Scriptum Digital 1:5-35

World Wide Web Consortium (2008) Extensible markup language (XML) 1.0 (fifth edition). Online at http://www.w3.org/TR/2008/REC-xml-20081126 